\title{
Address Forms Distinctive With the Stylized Use of Administrative Titles in Chinese Colleges and Universities
}

\author{
SHEN Shuang-sheng \\ Jiangsu University, Zhenjiang, China
}

\begin{abstract}
Address forms in Chinese colleges and universities are marked with the stylized use of administrative titles. This preferable use of administrative titles is not only the indication of interpersonal relationships but also the indication of favorable practices in the educational system, showing that staffs' statuses are marked with different ranks of power rather than academy. Administrative titles are in fact the indications of different ranks of power. The use of administrative titles originates from large power distance. Power in Chinese education is associated with wealth and privileges. Power becomes more powerful in an educational system in which the large power distance exists, because large power distance has created a psychologically shared cognition to worship power, and the cognition in turn intensifies the effects of power. The management of colleges and universities in China needs a great change; however, the change of the present situation first requires the change of the intellectuals themselves in their cognition.
\end{abstract}

Keywords: the stylized use of administrative titles in addressing, large power distance, worship of power, cognition

\section{Introduction}

Address forms are frequently used in interpersonal communications in daily life. Address forms constitute the first piece of the information transmitted to the addressees. Address forms are closely related to social, cultural, and political background and social norms, reflecting the users' attitudes and values. Address forms fall into different categories; there are alternatives of address forms to address the same person, and the choice of which is determined by the cognition and intentions of speakers who think they choose the most appropriate one in the given situations. The use of address forms is the indicator of interpersonal relationships and the pointer of characteristics of speakers and addressees as well. However, the use of preferable address forms in the colleges and universities in China is not only the indication of interpersonal relationships but also the indication of fashionable practices in the educational system, presenting a true picture for the understanding of the real conditions in which the staffs live and work.

\section{The Function of Address Forms}

Address forms are the words speakers use to designate the interlocutor, the third party, and themselves. They are the suitable titles or names that people use for someone when they are speaking to them. Address forms

SHEN Shuang-sheng, associate professor, master, School of Foreign Languages, Jiangsu University. 
basically function as social interaction. The use of address forms is the indicator of the subtle way in which the speakers and addressees define their relations to each other, and the speakers use them to identify themselves as pars of social group, establishing the kind of speech events they are in. When addressing a person, a number of factors should be weighed carefully before a speaker decides on a proper address forms, such as age, occupation, social status, identity, the setting of the conversation, the relative distance and the power between them, and emotions intended as well. Speakers often show their respect and politeness by depreciating themselves when addressing. The interpersonal relationship is in fact the social relationship between members of communities. Therefore, status is usually considered more important in communication between addressers and addressees, and social titles can be used in communication between members of communities. Address forms are the indication of the statuses of the addressees recognized by both addressors and addressees. Address forms involve references and vocatives, the former is used to refer to people and the latter is to greet and call people. Vocatives are used only for face-to-face communication while references may refer to the speaker, addressee, or others.

\section{Address Forms Marked With the Stylized Use of Administrative Titles in Colleges and Universities in China}

Address forms are the indicator of interpersonal relationships, and the reminder of the identities and social statuses of the addressees. The different address forms can be used to the same person or the same address forms can be used to the different persons depending on the settings and situations of certain conversations. The address forms in high education constituents in China mainly fall into four categories: general form, employment relation form, form of profession, and form of administrative titles. General form, such as "lao li or xiao Wang", can be used for everyone; this form founds its general use in any common situation of people's daily conversations. The employment relation form is marked by the term "boss", and "boss" is usually used by postgraduates to refer to their tutors, but not for addressing in the strict sense. Profession form is used for addressing teaching staff without any administrative titles, and the "teacher plus family names" is usually used in addressing instead of the use of academic titles, for instance, "teacher wang or teacher ma", but not "professor wang or professor ma"; in fact, this form is of a general use as well, for the term "teacher" is not special in colleges and universities. The administrative title is used for addressing the teaching staff with some administrative titles as well as those who work in the administrative departments. If one has any administrative title, and then this title is the must in addressing in any situations, even the addressee is a professor. The administrative title falls into different ranks such as president of colleges and universities, head of a department, section chief, and dean. In Chinese education, a president of colleges and universities is called "xiaozhang” or "yuanzhang"; a head of a department is called "chuzhang"; a head of a school under universities is also called "yuanzhang", and section chief or dean is called "zhuren". This form appears in the form of "family name plus an administrative title", for instance, "zhang chuzhang" in which "zhang" is the family name, and "chuzhang" is the head of a department. An administrative title is usually highlighted, even a person receives a vice administrative title, the word "vice" is naturally omitted in addressing and he or she is usually addressed with just that of administrative title. It is common to hear "family name plus an administrative title" such as "wang xiaozhang", "gao chuzhang", and "li zhuren" both in conversations and daily greetings in a college or university, and the addressers may be university staffs or students. In other words, administrative titles have found their constant use in any case for addressing regardless 
of settings and situations of any conversations. If the addressee has both an academic title such as professor and an administrative one such as head of a department, then his administrative one is unanimously made prominent in addressing. It has become an established rule that administrative titles always take priority over academic titles in addressing. In fact, academic titles such as "professor" and "lecturer" are seldom used in addressing. This fact reflects a commonly accepted cognition that the administrative titles are much more important than academic titles, and administrative titles are thought to be the suitable mark of staffs' statuses in colleges and universities. This shared cognition can be justified with the fact that there have been frequent cases in which groups of professors compete for heads of certain departments of colleges and universities, or some scholars get administrative titles by changing colleges and universities for which they work. In education, an academic title should be the appropriate mark for a scholar, but in colleges and universities of China administrative title is always superior to academic title, and it is used as a norm. In other words, the use of administrative titles in addressing has become stylization in colleges and universities. This cognition is shared by both the addressees and addressers, reflecting the dominant hierarchical orders established in high education constituents that are marked with administrative titles or ranks. Different administrative titles match with different powers on which the hierarchical orders are mainly built, which shows a dead fact that anyone with administrative title is privileged in colleges and universities. Although research and academy are outwardly encouraged and stressed in colleges and universities in China, academy is devalued under this circumstance. What is being performed is against what is being advocated for academic research in colleges and universities, which is like a person carrying fire in one hand and water in the other.

\section{The Cause Behind the Stylized Use of Administrative Titles for Addressing}

Address forms in Chinese colleges and universities show the user's emotion and cognition. According to Austin (1962), language is the way with which people perform actions. "Your speech reveals your disposition" (Weaver, as cited in HU, 1999, p. 329), so every use of speech, oral and writing, exhibits an attitude; and one’s cognition is shown with what one chooses to say. The stylized use of administrative titles for addressing shows the users' attitudes and cognition towards power; it reveals a special psychology, a psychology with which people worship power. "Inside organizations, inequality in power is inevitable and functional" (Hofstede, 2008, p. 79). In a society, the distribution of power is always not even just as the distribution of wealth, some people may have more say and power than others in social affairs. Power can be graded according to its function and importance. Some people may have some power to order others to perform certain actions they desire; some may have not such kind of power; some may have great, some small. If we use the concept of "distance” for the measurement of the power distribution, we can find that the power distance exists in different degrees in accordance with the different social systems. That is, there exist different distances to power for every civilian in a given society. Generally speaking, the power distance is relatively small in democratic societies, but in the society the operation of power is in the hands of minorities, the power distance is large. In a society of large power distance, there certainly exist great inequality and injustice among its civilians. And this power distance certainly manifests itself in its educational system. The stylized use of administrative titles for addressing in colleges and universities in China reflects the case, a large power distance between the ordinary staff and their higher-ups. The large power distance has created a shortage of interaction between the ordinary staff and their high-ups, and in the majority of 
cases the ordinary staffs are left into darkness about what decisions are to be made and how the decisions have been made. This long practice has given an accustomed illusion to the ordinary staffs that the decision-making is the affair of leaders of colleges and universities, and they are just the people who perform their duties to carry out all kinds of these decisions. In fact, this cognition reflects a psychological tendency that ordinary staffs are inferior to so called leading class in colleges and universities, and they themselves are even willing to be put under submission. Getting an administrative title is seen as the change and promotion of one's status. The receivers of administrative titles usually come from ordinary coworkers of the ordinary staffs. Before they have these titles, they address one another with "teacher plus family names" such as "teacher zhang or teacher ma". But after any of them receives an administrative title, the address form soon changes from "teacher plus family names" to administrative title. This change is not just a change of addressing, but a change of personal relationship, a change from the relationship of coworkers to that of subordinates and their higher-ups. This change has great significance, because a large power distance among them has appeared and exerted its influence accordingly.

The worship of power originates from the large power distance. Power distance has great to do with culture as well. The worship of power is deeply rooted in Chinese culture. In Chinese history, the great gap in power was maintained between the rulers and the common people; in the past, the common people were taught from the very young age to be loyal to their masters just as feudal officials remained a dead loyalty to their emperors. They were inclined to accept an idea that their gains of blessing were all granted by their masters. The feudal society of China was operated under a strict hierarchical order in which a master-servant relationship was deadly clear. For ordinary people, a possible change of fate could only be made by learning. In the past, people's hard efforts on learning were rewarded by some ranks of officials in accordance with their performances in examinations, as could be justified with the imperial examination system, and the system has been practiced for more than one thousand years. The change of fate for common people was tough. However, once the change was made successful, then the fates of both his and other members of his family would change from servant to master as well. Therefore, to become officials was the desired goal for those who were on their way of learning in the Chinese feudal society. And anyone who once was rewarded as an official for his hard effort on learning meant that he had struggled successfully out from laboring peasants, or "like sharp leaping into the Dragon's Gate”, the old Chinese saying meaning getting rapid promotion as a master. The master possessed power. The masters had someone put their services under him. The master could issue orders to his men out of his own free will, and he was capable of determining the fates of his servants. The master's authority could not be challenged, and any challenge would bring disaster to the challenger himself as well as his family. This phenomenon attributed to the large power distance, and what could be done with power had profound magnificence on people's psychology from generation to generation. In the past, children were taught from the very young age to work hard on learning to become some ranks of officials, for the reward for learning as officials was seen as glories and honors to their families and ancestors. This psychology extends from the past till today, and it still has its strong effect in many spheres of social life; today there are still some people taking desperate efforts to become the members of so-called ruling class by all kinds of possible means including learning. Man is material-oriented in nature. Power in China is usually associated with privileges and wealth, and anyone with power enjoys privileges in all kinds of social affairs. The case is the same that persons with administrative titles enjoy much more privileges than those 
without in educational system. In colleges and universities, persons with administrative titles usually have great influence in deciding on other working staffs' academic titles; if one receives an administrative title before an academic one, then his academic title is much easier to be handled; usually ones with abundant researching achievements are those with administrative titles in Chinese colleges and universities, though most of their energy are always put into other affairs rather than true researching, and all achievements including research are considered the outcomes under their leadership. Persons with administrative titles have more say over affairs concerning all staff's interests. Although some teachers are nominated to take part in the consultancy of decision making, in reality decision-making is in university officials' hands. The large power distance, as it functions in other spheres in social life, functions in colleges and universities in the same manner as well. The large power distance has created a psychological gap between the leaders and the ordinary working staffs in educational system. And this gap can be a barrier for a true cooperation and a big obstacle for progression.

\section{What Effect the Stylized Use of Administrative Titles Has in the Perspective of Language}

Language is the map of the reality, what is performed in reality will show itself in the use of language. The use of language is the reflection of one's thinking, and the thinking in return shapes the modes of the users' use of language. "language is a system of imputation, by which values and percepts are first framed in the mind and are then imputed to things" (as cited in HU, 1999, p. 330). The stylized use of administrative titles in addressing can shape the modes of use of language for both new comers working at universities and college students, especially for young students in colleges and universities. They will become accustomed to use administrative titles for addressing, and this heritage can intensify the willing acceptance of large power distance in educational system. This cognition, or a way of thinking, can be handed down in colleges and universities by the way of "meme" (Dawkins, 1976). From cultural respect, the mode of addressing can be copied and transmitted from one to another among the members of communities. The use of address forms, on the surface, embodies the interpersonal function (Halliday, 1976) of the language, and this interpersonal function embodies itself with strong emotion and cognition, but in essence, the use reveals inequality in high education system. This existing inequality is caused by power distance. Strictly speaking, inequality exists in different degrees in different societies, and the degree of which is of direct proportion to the power distance. However, in the society of the large power distance, inequality must be much accordingly and can even go to a harmful extent. Because the right to run colleges and universities is in the possession of politicians of colleges and universities, not in hands of educators, and the policy-making is administratively beneficial-oriented; the policy about distribution of income serves as a case in recent years. Although working staffs live and work in the same college and university, but they are kept away from participation in affairs concerning their interests because of large power distance. Large power distance leads to a lack of interaction among staffs as well. This has resulted in a deformed personal relationship in which minorities of the working staffs are made closer in distance and relation to those who have power but majorities are made further in distance and relation; it has created a personal relationship from core to margin, and some are marginalized. The division is created and maintained among working staffs with administrative power. And this division can be a great barrier for a true cooperation. Large power distance has created passiveness for ordinary staffs in colleges and universities as well. The working staffs are treated as those who should only carry out all kinds of policies, not the participants of policy-making. This practice has made the 
ordinary working staffs inferior in college affairs, and this disadvantage can hinder them from bringing their potentials into full play. Inequality arises.

This inequality results from large power distance, and the large power distance creates the particular hierarchy in Chinese educational system. The human society is based on the hierarchical system, and it is natural that there are hierarchies in colleges and universities as well, for instance, there must be different ranks in academy matching with different abilities and experiences in one's research. The problem is not hierarchy itself, but how the hierarchy is built and functions. The hierarchy in high education constituents in China is in fact built on administrative ranks. This may encourage the working staffs to try to obtain administrative titles rather than focus their energy on true research and teaching. Once administrative titles serve as the key and first measurement for ones' status in colleges and universities, then these colleges and universities are surely operated in a flawed evaluation and deficient supervising system in which violation of the basic principles of education frequently occurs. The frequent occurrences of false academic achievements serve as good examples. Colleges and universities should be the place that not only knowledge is passed on and truth is sought, but also justice men cultivated. Intellectuals represent a trend of thinking giving a direction for the future development, and this direction is at least human civilization-oriented, aiming at the establishment of a reasonable social order with equality and justice. The stylized use of administrative titles for addressing reflects the psychological tendency of worshiping power, and this tendency produces shortage of independent personality in Chinese intellectuals. Independent personality is the prerequisite for an intellectual to seek truth, especially for those who are engaged in humanities research. Independent personality involves the correct cognition and correct attitudes towards power, equality and justice, and one's value as well. Intellectuals in Chinese education should find their independent personality back from the worship of power. Independent personality is absolutely necessary for researching and teaching, without which the colleges and universities operate in a way like a dead-alive person behaving without a worthy spirit focusing merely on material gains and are doomed to become Vanity Fairs.

\section{Conclusion}

This paper has dealt with the address forms in Chinese colleges and universities. It has found that administrative titles are unanimously used in any conversations and daily greetings. They are highly prominent and considered the desired mark for ones' statuses. Administrative titles are associated with power, and power is associated with wealth and privileges. Address forms constitute the first piece of the information transmitted to the addressees. The stylized use of administrative titles for addressing determines that the basic communications go under the unequal atmosphere at the very beginning. It reflects a psychological tendency of staffs working at colleges and universities that anyone who has an administrative title is superior to those who have not. The cognition originates from large power distance, which is the real course of inequality. It does not mean that the author has some negative attitude towards those who have administrative titles, and the author only questions the fashionable practice, or the present hierarchy built on different ranks of administrative power in high education system, because this practice has violated the basic principle for the operation of true education. The change of the situation needs the change of the Chinese present education system, also needs change of staffs' cognition, for the true change is the change of men in their cognition. 


\section{References}

Austin, J. L. (1962). How to do things with words?. Oxford: The Clarendon Press.

CAI, J. G. (2012). “学术英语” 课程需求分析和教学方法研究 (Demanding analysis and teaching of “English for Academic

Purposes”). Theory and Practice of Foreign Languages, (2), 30-35.

Dawkins, R. (1976). The selfish Gene. New York: Oxford University Press.

Fishman, J. A. (1972). The sociology of language. In P. P. Giglioli (Ed.), Language and social context: Selected readings (pp. 45-58). Harmondsworth: Penguim.

Halliday, M. A. K. (1973). Explorations in the function of language. London: Edward Arnold.

Hofstede, G. (2008). Culture's consequences: Comparing values, behaviors, institutions and organizations across nations. Shanghai: Shanghai foreign language education press.

HU, S. Z. (1999). New rhetoric in America. Shanghai: Shanghai Foreign Language Education Press.

WANG, C. L. (2001). 敬畏教育 (Reverence to education). Changchun: Jilin People’s Press. 